\title{
Plumage brightness predicts non-breeding season territory quality in a long-distance migratory songbird, the American redstart Setophaga ruticilla
}

\author{
Matthew W. Reudink, Colin E. Studds, Peter P. Marra, T. Kurt Kyser and Laurene M. Ratcliffe \\ M. W. Reudink (correspondence) and L. M. Ratcliffe, Dept. of Biology, Queen's Univ., Kingston, ON K7L 3 N6 Canada and Smithsonian \\ Migr. Bird Center, 3001 Connecticut Ave. NW, Washington, DC 20008 USA. Email: mattreudink@gmail.com. - C. E. Studds and P. P. \\ Marra, Smithsonian Migr. Bird Center, 3001 Connecticut Ave. NW, Washington, DC 20008 USA. - T. K. Kyser,Dept. of Geological Sciences \\ and Engineering, Queen's Univ., Kingston, ON K7L 3N6 Canada.
}

\begin{abstract}
Many species of birds exhibit brilliant ornamental plumage, yet most research on the function and evolution of plumage has been confined to the breeding season. In the American redstart Setophaga ruticilla, a long-distance NeotropicalNearctic migratory bird, the acquisition of a winter territory in high-quality habitat advances spring departure and subsequent arrival on breeding areas, and increases reproductive success and annual survival. Here, we show that males holding winter territories in high-quality, black mangrove habitats in Jamaica have brighter yellow-orange tail feathers than males occupying territories in poor-quality second-growth scrub habitats. Moreover, males arriving on the breeding grounds from higher-quality winter habitats (inferred by stable-carbon isotopes) also had brighter tail feathers. Because behavioral dominance plays an important role in the acquisition of winter territories, plumage brightness may also be related to fighting ability and the acquisition and maintenance of territories in high-quality habitat. These results highlight the need for further research on the relationships between plumage coloration, behavior, and the ecology of over-wintering migratory birds.
\end{abstract}

Study of the function of plumage coloration during the breeding season has informed much of what we know about the elaboration of ornamental traits through sexual selection and female choice (Hill 2006). In many species, plumage is highly variable and phenotypically plastic and can be influenced by both the environment (Linville and Breitwisch 1997, McGraw and Hill 2001), and individual condition at the time of molt (Figuerola et al 2003, Saks et al. 2003). This variation in plumage coloration can be used by conspecifics to gather information about an individual's quality as a potential mate or competitor (Zahavi 1977, Andersson 1994). Many breeding season studies have now confirmed that females can use this information to inform social (e.g., Hill 1990, Johnsen et al. 1998, MacDougall and Montgomerie 2003, Senar et al. 2005, for review, see Hill 2006), and extra-pair mating decisions (Sundberg and Dixon 1996, Yerzinac and Weatherhead 1997, Thusius et al. 2001) - the result of which can lead to increased variance in male mating success and the elaboration of ornamental traits (Albrecht et al. 2007, Dolan et al. 2007, Webster et al. 2007).

However, plumage can also function as a signal of individual quality during the non-breeding season. Variation in plumage coloration can indicate social dominance (Maynard Smith and Harper 1988, Mennill et al. 2003), and experimental studies have shown that manipulation of signals can alter dominance status (Peek 1972, Rohwer 1985, Holberton et al. 1989, Pryke et al. 2002, Pryke and Andersson 2003), suggesting that social selection can be an important force in the evolution of plumage traits (for review, see Senar 2006). Yet, despite the widespread evidence for plumage-based status signaling systems in temperate (and some tropical) species, little is known about whether plumage functions as a signal in migratory birds during the non-breeding season (but see Stutchbury 1994). This is not surprising given the relative paucity of information on the over-wintering ecology and behavior of migratory birds (Greenberg and Marra 2005). By examining only one phase of the annual cycle, we ignore potential factors that may influence the evolution of ornamental plumage. This work is of particular relevance, as new studies are beginning to reveal how non-breeding season events may influence an individual's life-history traits, ecology, and behavior (e.g. Studds et al. 2008).

For plumage to act as a status signal, it must advertise information about an individual's dominance status or competitive ability (Rohwer 1975). These plumage-based signals may include, but are not limited to, badge size (e.g., epaulet size: Eckert and Weatherhead 1987, bib size: Møller 1987, McGraw et al. 2003) or coloration based on melanin 
(Mennill et al. 2003), carotenoids (Wolfenbarger 1999, McGraw and Hill 2000, Pryke et al. 2002), or feather microstructure (Alonso-Alvarez et al. 2004). Melanin is synthesized internally from amino acids and is not acquired directly from the diet (Hill 2002), although the honesty of the signal may be maintained by nutrient limitation (McGraw 2007) and social reinforcement mechanisms (Senar 2006), or mediated by testosterone levels during molt (Hill 2002). Carotenoids cannot be synthesized naturally, and therefore must be ingested through diet, modified (depending on the pigment), and deposited (Hill 2002, 2006). Thus, only males in good condition with access to high-quality food should be able to signal with carotenoid pigments, making this a potential honest indicator of male quality (Hill 1999, Pryke et al. 2001).

For a plumage-based status signaling system to exist, there must be variation in plumage that can be used to assess individual quality and a system in which assessing the fighting ability or dominance status of consepecifics confers an advantage (Rohwer 1975). American redstarts Setophaga ruticilla, a small long-distance migratory songbird, are ideally suited to the study of plumage-based signaling during the nonbreeding period. American redstarts are highly variable in both carotenoid- and melanin-based plumage (Sherry and Holmes 1997; see Methods, Study species), and dominance relationships play a critical role in obtaining and maintaining high-quality winter territories (Marra 2000). Furthermore, redstarts use a distinctive tail fanning display during aggressive interactions (Sherry and Holmes 1997), suggesting that aspects of tail coloration could be important signals. Dominance behavior and competitive interactions lead to age- and sex-biased habitat segregation, with adult males occupying the majority of territories in high-quality habitats in our study sites in Jamaica (Marra et al. 1993, Marra 2000). Individuals overwintering in high-quality, mangrove territories experience higher food availability than those in second-growth scrub and this influences arrival date and reproductive success on breeding areas (Marra et al. 1998, Norris et al. 2004a, Studds and Marra 2007), as well as annual return rates (Marra and Holmes 2001). Interestingly, female redstarts able to acquire and maintain territories in high-quality habitats are larger and more aggressive than females in poorquality habitat (Marra 2000). However, male redstarts do not differ in body size between habitat types (Marra 2000). One hypothesis for this sex-specific difference is that for males, territory acquisition is mediated through plumagebased status signaling.

Here, we test if plumage coloration is associated with territory occupancy across a habitat quality gradient in Jamaica. Specifically, we test for differences in brightness, chroma, and hue in tail feathers of male American redstarts holding territories in black mangrove forest (high-quality), and second-growth scrub (low-quality). Additionally, we test if the relationship between plumage color and winter habitat quality carries over onto the breeding grounds in Ontario, Canada.

\section{Methods}

\section{Study species}

Our study species was the American redstart, a small (7-8 g) and widespread Nearctic- Neotropical migratory songbird. American redstarts breed throughout much of North America and winter throughout the Caribbean, Mexico, and parts of Central and northern South America (Sherry and Holmes 1997). Recent work suggests that American redstarts over-wintering in the Caribbean breed in the northeastern United States and southeastern Canada, including Ontario (Norris et al. 2006). American redstarts are sexually dimorphic; males exhibit delayed plumage maturation, with highly variable plumage coloration both within and between age classes. Individuals undergo a single pre-basic molt at the end of the breeding season and retain those feathers through the following breeding season (Sherry and Holmes 1997). In their first winter (and subsequent breeding season), males are greenish-gray with yellow carotenoid-based patches on their wings, tail, and flanks. These males lack bibs entirely, but some individuals adventitiously molt in small patches of black feathers on the breast, back and head during winter. After their first breeding season, males molt into their definitive plumage: black upperparts and head with a white belly, salmonorange carotenoid-based patches on the wings, tail and flanks and a black bib (Sherry and Holmes 1997). Studies from the breeding grounds suggest that bib size is related to breeding-season performance (Perrault et al. 1997), though the function of the carotenoid-based patches has not yet been investigated.

\section{Study sites}

Over-wintering American redstarts were captured in highquality (black mangrove) and low-quality (second-growth scrub) habitats from Dec.-March 2002-2006 at Font Hill Nature Preserve, Westmoreland Parish, Jamaica, West Indies $\left(18^{\circ} 02^{\prime} \mathrm{N}, 77^{\circ} 57^{\prime} \mathrm{W}\right.$; see Marra 2000). Sample numbers varied yearly based on accessibility to different habitats and the duration of our stay. Work on the breeding grounds was conducted May-July 2006 at the Queen's Univ. Biological Station, Chaffey's Lock, Ontario, Canada ( $\left.44^{\circ} 34^{\prime} \mathrm{N}, 76^{\circ} 19^{\prime} \mathrm{W}\right)$.

\section{Tissue sampling}

All birds were captured in mist nets either through passive blanket netting or using song playbacks accompanied by a decoy, and banded with a single US Fish and Wildlife Service or Canadian Wildlife Service band and 2-3 color bands for individual identification. On the breeding grounds in May 2006, birds were captured within $5 \mathrm{~d}$ of arrival and $2-3 \mathrm{~mm}$ of the central claw from each foot was collected; claw samples in Jamaica were obtained in March 2006. For all birds, we recorded wing chord ( $\mathrm{mm}$ ) and 
plucked a single tail feather (R3) for color and stablehydrogen isotope analysis.

\section{Color analysis and bib size scoring}

Reflectance spectra from tail feathers was obtained by measuring percent reflectance across the bird visual spectrum (320-700 nm) using an Ocean Optics USB2000 spectrometer attached to a PX-2 xenon pulsed light source. The probe was held at a $90^{\circ}$ angle to the feather surface and housed in a rubber sheath to keep the probe at a constant distance from the feather surface and ensure we captured light only from the PX-2 light source. All feathers were mounted on minimally reflective $(<5 \%$ reflectance) black

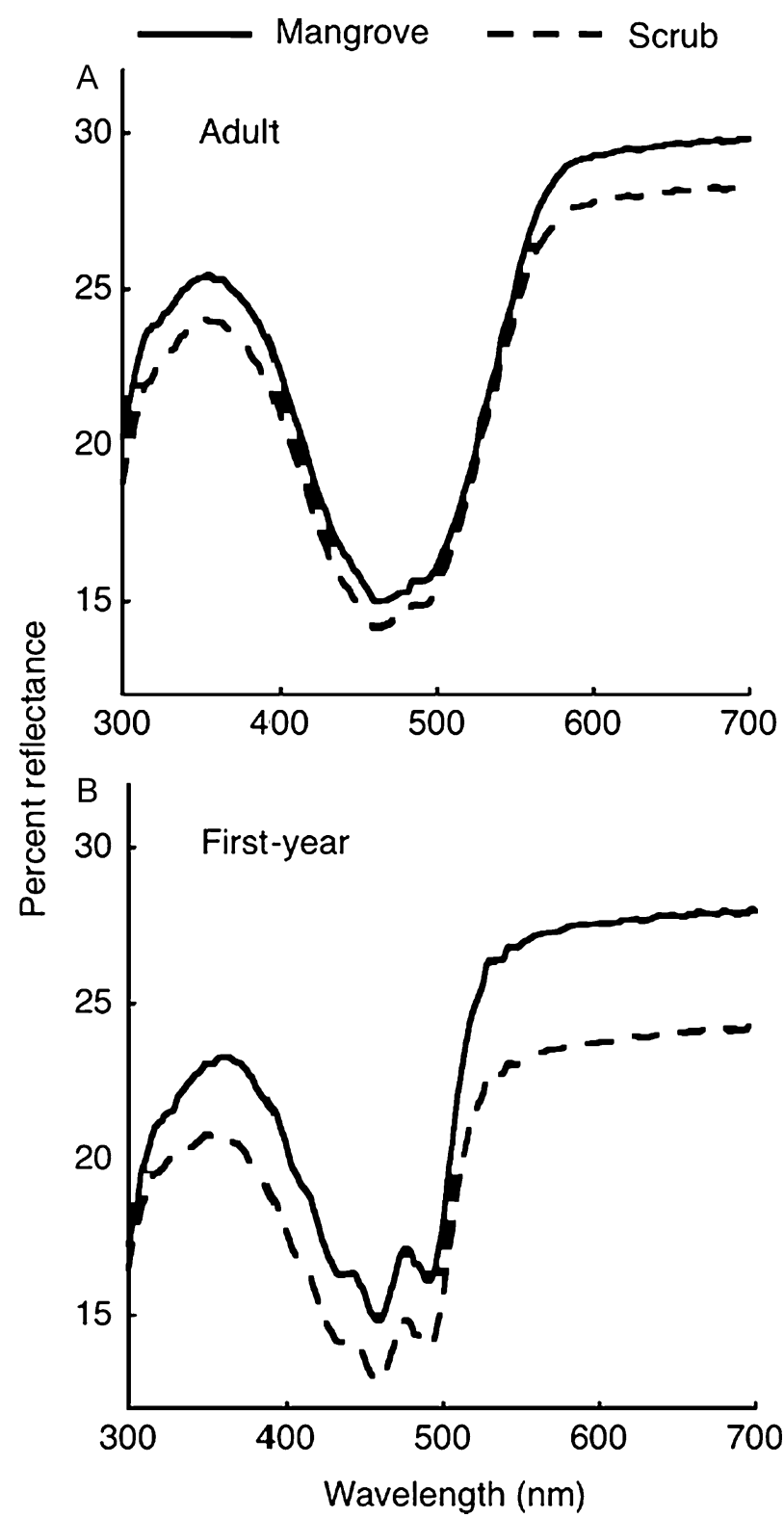

Figure 1. Average reflectance spectra from the yellow-orange region of the tail feather (R3) in: (A) adult males, and (B) firstyear males holding territories in high-quality black mangrove forest (black line: adult, $n=24$; first-year, $n=12$ ) and low-quality second-growth scrub (gray line: adult, $\mathrm{n}=14$; first-year, $\mathrm{n}=12$ ). paper (Colorline \#142 Ebony). To standardize our measurements, we took readings from a dark (sealed black velvet lined box) and white (spectralon) standard between each measurement. Three to five measurements were taken haphazardly within the yellow/orange region of each tail feather, avoiding the rachis (see Fig. 1 for reflectance spectra). Tail feathers were chosen for our analysis because they are frequently fanned in aggressive displays (Sherry and Holmes 1997). Plumage coloration was quantified by calculating standard measures of brightness, hue, and chroma (Montgomerie 2006; Table 1). Brightness was calculated as the mean reflectance across the bird visual spectrum (320-700 nm). Hue was calculated via segment classification (adapted from Endler 1990; Montgomerie 2006; Table 1). Because American redstart feathers exhibit two distinct spectral peaks (UV and yellow/red), we measured both UV and red chroma, which is the light reflected in the UV or red portion of the spectrum (320 $415 \mathrm{~nm}$ and $575-700 \mathrm{~nm}$ respectively) divided by the total reflectance. Bib size was ranked in the hand on a scale of 1-5 (1 = small, $5=$ large; Lemon et al. 1992).

\section{Stable-carbon isotope analysis}

Because of differences in plant water stress and photosynthetic system, $\delta^{13} \mathrm{C}$ signatures in plant tissues vary among different habitat types in the tropics (Lajtha and Marshall 1994). $C_{3}$ plants and plants experiencing little water stress generally have more negative $\delta^{13} \mathrm{C}$ signatures compared to $\mathrm{C}_{4}$ plants and water-stressed plants (Lajtha and Marshall 1994). These signatures are transferred up the food chain, and eventually incorporated into birds' tissues. Thus, by sampling bird tissues, such as claws, on arrival in Canada, we can infer information about the habitat that bird occupied during the non-breeding period (Marra et al. 1998). In Jamaica, black mangrove forests are inundated with water for much of the year and plants experience less water-stress than the highly seasonal second-growth scrub, resulting in more negative $\delta^{13} \mathrm{C}$ signatures in plants and animals in that environment (Marra et al. 1998). Thus, by capturing birds upon arrival on the breeding grounds, it is possible to infer the quality of winter habitat. In separate populations of breeding American redstarts, Marra et al. (1998) and Norris et al. (2004a) showed that birds arriving earlier on the breeding grounds had more negative $\delta^{13} \mathrm{C}$ signatures. Furthermore, Norris et al. (2004a) found birds with more negative $\delta^{13} \mathrm{C}$ signatures ultimately had higher reproductive success. Compared to blood, $\delta^{13} \mathrm{C}$ in claw tissues has a relatively slow turnover rate (weeks to months)

Table 1. Formulas used to calculate color variables. Percent reflectance was measured at each $1 \mathrm{~nm}$ interval across the spectrum. $\mathrm{B}_{\lambda} \mathrm{i}-\mathrm{n}=$ total light reflected from the $i$ th wavelength to the $n$th wavelength $(\delta \mathrm{i}-\delta \mathrm{n})$ after summing across each $1 \mathrm{~nm}$ interval. $\mathrm{n}=$ the number of $1 \mathrm{~nm}$ intervals between $\delta \mathrm{i}-\delta \mathrm{n}$.

\begin{tabular}{ll}
\hline Color variable & \multicolumn{1}{c}{ Formula } \\
\hline Brightness & $\mathrm{B}_{\lambda 320-700}=\Sigma_{\lambda 320}^{\lambda 700} / \mathrm{n}$ \\
UV chroma & $\mathrm{C}_{U V}=\mathrm{B}_{\lambda 320-415} / \mathrm{B}_{\lambda 320-700}$ \\
Red chroma & $\mathrm{C}_{\text {red }}=\mathrm{B}_{\lambda 575-700} / \mathrm{B}_{\lambda 320-700}$ \\
Hue & $\mathrm{H}=\arctan \left(\left[\left(\mathrm{B}_{\lambda 512-575}-\mathrm{B}_{\lambda 320-400}\right) / \mathrm{B}_{\lambda 320-700}\right] /\right.$ \\
& $\left.\left[\left(\mathrm{B}_{\lambda 575-700}-\mathrm{B}_{\lambda 400-512}\right) / \mathrm{B}_{\lambda 320-700}\right]\right)$ \\
\hline
\end{tabular}


and, for studies of migratory birds, this signature should be retained post-arrival on the breeding grounds, though some integration of local isotopic signatures may occur (Bearhop et al. 2003, 2004). For this study we included only birds that arrived within $25 \mathrm{~d}$ of the first bird to arrive on the breeding grounds. Claws samples were weighed, then converted to $\mathrm{CO}_{2}$ in an oxidation/reduction furnace, separated by gas chromatography, then measured for $\delta^{13} \mathrm{C}$ with an isotope-ratio mass spectrometer (Lajtha and Marshall 1994, Norris et al. 2004a).

\section{Stable-hydrogen isotope analysis}

Previous work on American redstarts suggested that plumage coloration varies geographically, with birds molting feathers at more northerly latitudes having more red chroma than those birds molting at more southerly latitudes (Norris et al. 2007), and that some birds that invest heavily in late-season parental effort may molt south of the breeding grounds, resulting in duller plumage (Norris et al. 2004b). Because our wintering population breeds across a relatively large geographic range (Studds et al. $2008)$, we used stable-hydrogen isotope $(\delta D)$ analysis to determine if there was a relationship between molt location and brightness or red chroma and if molt location helped explain winter habitat occupancy. Details of our stablehydrogen isotope analysis are reported in Langin et al. (2007). Briefly, all feathers were washed in a 2:1 chloroform:methanol solution, $0.1-0.15 \mathrm{mg}$ of feather was weighed and combusted in a Finnigan TC/EA reduction furnace at $1,450^{\circ} \mathrm{C}$ and introduced into a Finnigan MAT Delta Plus XL isotope ratio mass spectrometer. All $\delta \mathrm{D}$ values are reported in parts per mil notation $(\%)$ relative to Vienna Standard Mean Ocean Water. Only feathers from adult males were used in this analysis.

\section{Statistical analyses}

Each component of redstart feather color (brightness, UV chroma, red chroma, and hue) was analyzed separately. Data on feather color of birds captured in Jamaica were examined by using analysis of variance (ANOVA) with habitat and bird age as main effects. Unflattened wing chord was included in the model as a linear covariate to adjust for variation in feather color due to body size differences. Due to small sample sizes, we pooled data from multiple years (2002: $\mathrm{n}=5$ adult, 0 first-year; 2003: $\mathrm{n}=3$ adult, 0 first-year; 2004: $\mathrm{n}=11$ adult, 1 first-year; 2005: $\mathrm{n}=17$ adult, 16 first-year; 2006: $\mathrm{n}=2$ adult, 7 first-year). Because of uneven sampling of adult and first-year males in different years, we cannot clearly differentiate between age effects and year effects; however, we have no a priori reason to expect differences between years in which a higher proportion of adults or first-year males were captured. Differences in bib size between adult males over-wintering in mangrove and scrub habitats were analyzed with an independent samples $t$-test. The relationship between feather color and stable-carbon isotope ratios in the claws of redstarts arriving in Ontario was evaluated by using linear regression. To validate that stable-carbon isotope ratios in claws reflect moisture gradients in nonbreeding habitat, we also evaluated differences between claws of Jamaican birds occupying mangrove and scrub habitats. The residuals of this analysis were markedly non-normal and were therefore analyzed with a Wilcoxon rank-sum test. The effect of molting latitude on feather color was analyzed by using linear regression. All tests were performed in JMP 6.0.2 (SAS 2006).

\section{Results}

\section{Relationship between habitat, bird age and plumage color}

Tail feathers of redstarts occupying territories in black mangrove habitat were brighter than those of birds holding territories in second-growth scrub, but did not differ in UV chroma, red chroma, or hue (Table 2). Feathers of adult males had significantly higher UV chroma, red chroma, and redder hue compared to first-year males. Birds with longer wings had significantly brighter feathers, but did not have higher UV chroma, red chroma, or redder hue (Table 2). $\mathrm{Bib}$ size of adult males did not differ between habitats (independent samples t-test: $\mathrm{t}_{22}=1.21, \mathrm{P}=0.24$ ).

Table 2. Color variables (mean \pm SE) calculated from reflectance spectra of adult and first-year males in over-wintering in high-quality black mangrove forest and low-quality second-growth scrub. Bottom of table shows the results of a two-way ANOVA with age, habitat and wing length as main effects and a habitat $\times$ age interaction term (first-year males: $n=12$ mangrove, 12 scrub; adult males: $n=24$ mangrove, 14 scrub). Bolded values are significant at $\alpha=0.05$.

\begin{tabular}{|c|c|c|c|c|c|}
\hline Age & Habitat & Brightness & UV chroma & Red chroma & Hue \\
\hline \multirow[t]{3}{*}{ Adult } & Combined & $23.46 \pm 0.52$ & $0.22 \pm 0.002$ & $0.41 \pm 0.005$ & $-0.02 \pm 0.01$ \\
\hline & Scrub & $22.56 \pm 0.93$ & $0.22 \pm 0.004$ & $0.41 \pm 0.008$ & $-0.06 \pm 0.02$ \\
\hline & Mangrove & $24.00 \pm 0.63$ & $0.22 \pm 0.003$ & $0.41 \pm 0.006$ & $-0.02 \pm 0.01$ \\
\hline \multirow[t]{3}{*}{ First-year } & Combined & $21.72 \pm 0.63$ & $0.21 \pm 0.003$ & $0.39 \pm 0.004$ & $0.06 \pm 0.03$ \\
\hline & Scrub & $20.17 \pm 0.89$ & $0.21 \pm 0.005$ & $0.39 \pm 0.006$ & $0.04 \pm 0.04$ \\
\hline & Mangrove & $23.26 \pm 0.68$ & $0.20 \pm 0.004$ & $0.39 \pm 0.006$ & $0.08 \pm 0.03$ \\
\hline \multirow[t]{2}{*}{ Effect of age } & & $F=0 . \overline{82}$ & $\mathrm{~F}=4.92$ & $F=5.34$ & $\mathrm{~F}=6.90$ \\
\hline & & $P=0.37$ & $P=0.03$ & $P=0.02$ & $P=0.01$ \\
\hline \multirow{2}{*}{ Effect of habitat } & & $F=9.90$ & $F=0.06$ & $F=0.08$ & $F=0.74$ \\
\hline & & $P=0.003$ & $P=0.80$ & $P=0.78$ & $P=0.39$ \\
\hline \multirow[t]{2}{*}{ Effect of habitat $\times$ age } & & $F=1.80$ & $\mathrm{~F}=-0.40$ & $F=0.06$ & $F=0.01$ \\
\hline & & $P=0.08$ & $P=0.69$ & $P=0.81$ & $P=0.91$ \\
\hline \multirow{2}{*}{ Effect of wing length } & & $F=2.62$ & $F=1.50$ & $F=0.22$ & $\mathrm{~F}=2.64$ \\
\hline & & $P=0.01$ & $P=0.14$ & $P=0.64$ & $P=0.11$ \\
\hline
\end{tabular}




\section{Relationship between habitat (stable-carbon isotopes) and plumage color}

Stable-carbon isotope signatures $\left(\delta^{13} \mathrm{C}\right)$ in claws of adult males sampled in mangrove habitats in Jamaica were significantly more negative than those sampled in scrub habitats (Wilcoxon rank-sum test, $\mathrm{z}=2.66, \mathrm{P}=0.008$, $\mathrm{n}=26$; Fig. 2A). Adult males arriving on the breeding grounds with signatures consistent with high-quality, wet non-breeding season habitats (more negative $\delta^{13} \mathrm{C}$ signatures) had brighter plumage $\left(\mathrm{r}^{2}=0.31, \mathrm{P}=0.03, \mathrm{n}=15\right.$; Fig. $2 \mathrm{~B})$, but not $\mathrm{UV}$ chroma $\left(\mathrm{r}^{2}=0.15, \mathrm{P}=0.14, \mathrm{n}=15\right)$, red chroma $\left(\mathrm{r}^{2}<0.001, \mathrm{P}=0.96, \mathrm{n}=15\right)$, hue $\left(\mathrm{r}^{2}=0.009\right.$, $\mathrm{P}=0.74, \mathrm{n}=15)$, or bib size $\left(\mathrm{r}^{2}=0.06, \mathrm{P}=0.35, \mathrm{n}=16\right)$.
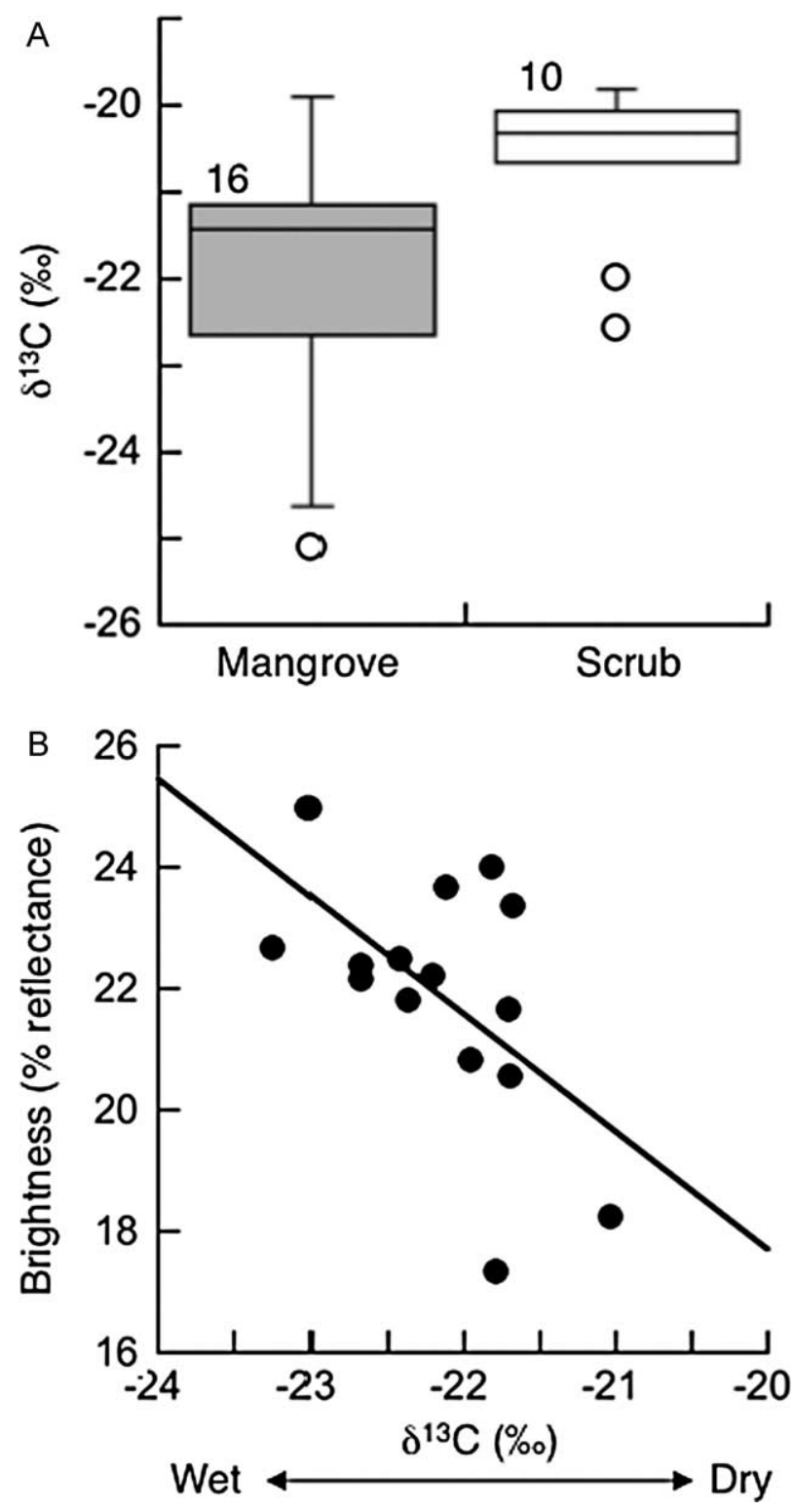

Figure 2. (A) $\delta^{13} \mathrm{C}$ signatures in claws of birds collected in mangrove and scrub habitats. Sample size is indicated on top of the boxes; horizontal lines represent 90th, 75th, 50th, 25th, and 10 th percentiles. (B) Relationship between brightness and $\delta^{3} \mathrm{C}$ in claws $(n=15)$ collected upon arrival on the breeding grounds in Canada. Birds from wetter winter habitats (more negative $\delta^{13} \mathrm{C}$ signatures) have higher brightness; regression line shown.

\section{Relationship between molting latitude $(\delta \mathrm{D})$ and plumage color/habitat}

Stable-hydrogen isotope analysis revealed that our Jamaica population of over-wintering redstarts molted over a broad geographic range ( $\delta \mathrm{D}$ range: -59 to -100$)$. We detected no relationship between $\delta \mathrm{D}$ and brightness $\left(\mathrm{r}^{2}=0.08\right.$, $\mathrm{P}=0.15, \mathrm{n}=26)$, red chroma $\left(\mathrm{r}^{2}<0.001, \mathrm{P}=0.92, \mathrm{n}=\right.$ 26), UV chroma $\left(r^{2}<0.001, P=0.93, n=26\right)$, or hue $\left(r^{2}=0.06, P=0.39, n=26\right)$. Furthermore, we found no difference in $\delta \mathrm{D}$ between habitat types (two-tailed t-test, $\left.\mathrm{t}_{26}=1.37, \mathrm{P}=0.18\right)$.

\section{Discussion}

In this study we used two different approaches to demonstrate that the brightness of a carotenoid-based plumage patch, molted at the end of the breeding season, is associated with occupancy of high-quality winter habitats. In our first approach we showed that birds in Jamaica holding territories in high-quality black mangrove forest have brighter tail feathers than birds in low-quality secondgrowth scrub. We controlled for both age and wing length in our analyses and demonstrated that plumage brightness predicts habitat occupancy in both age-classes, and does so beyond any effect of body size. Second, we tested if this pattern carried over to the breeding period and was detectable over broad spatial scales (i.e., for birds likely over-wintering in a range of habitat types) and found that birds arriving on the breeding grounds in Ontario, Canada from higher-quality winter habitats (inferred by stablecarbon isotope analysis) were brighter than birds arriving from poor quality habitats. Our ability to detect a relationship between habitat quality $\left(\delta^{13} \mathrm{C}\right)$ and plumage brightness is surprising because redstarts breeding at our Ontario study site are likely arriving from a variety of winter localities (see Methods: Study species) and suggests that the relationship between plumage brightness and winter habitat occupancy occurs at broad spatial scales and across various habitat types. Because dominance and aggression play a critical role in territory acquisition in American redstarts (Marra 2000), we suggest that the most plausible explanation of our results is that plumage brightness serves as a status signal, indicating superior fighting ability.

Under this scenario, habitat-specific plumage variation may arise from differences in dominance and competitive ability, where brighter birds out-compete less bright birds for high-quality territories. Previous work on American redstarts in Jamaica has shown that all age- and sex-classes initially settle disproportionately in high-quality, mangrove habitats, but that most females and first-year males are subsequently displaced, generally by adult males (Marra 2000). These displacements are driven both by prior residents (i.e., color-banded birds that held territories in the previous year) and by newly arriving birds, suggesting that both prior residency and intrinsic dominance are important in determining the outcomes of dominance interactions. Also, playback experiments demonstrate that birds in mangrove territories show higher aggressive territorial responses compared to those in scrub, suggesting that differences in aggression likely determine the outcome 
of dominance-based territory occupancy (Marra 2000). However, additional experiments are necessary to determine if plumage brightness reflects competitive ability and aggression. For example, it would be informative to measure the intensity of aggressive encounters (e.g., by presenting models and vocalization playbacks to territory holders, Marra 2000) in relation to male plumage or examine the effects of plumage manipulations on males' ability to obtain and retain a territory in high-quality habitat. Furthermore, if feather brightness is indeed acting as a status signal, it will be necessary to understand the mechanisms that maintain signal honesty.

Our finding that feather brightness, not red chroma, is positively related to territory quality is counter-intuitive. Generally, yellow-orange plumage coloration acts as an honest signal of quality by revealing carotenoid deposition, whereby increasing carotenoid deposition increases red chroma and decreases feather brightness (Andersson and Prager 2006). However, highly reflective (bright) yelloworange coloration is the product of both carotenoid deposition and structural coloration (Shawkey and Hill 2005), and brightness has been shown to be an indicator of condition and quality (Saks et al. 2003, Stein and Uy 2006). Regardless of the mechanisms that lead to increased brightness, our results indicate that plumage brightness is a good predictor of habitat quality and suggests that further investigation is warranted.

Factors other than dominance-based status signaling might also be responsible for our observed patterns of habitat-specific plumage variation. One possible explanation is that birds in the more open, scrub habitat may be exposed to harsher environmental conditions, such as UV irradiation and feather abrasion, leading to decreased feather reflectance. Plumage of male linnets Carduelis cannabina exposed to higher sunlight UV irradiation increased in hue, saturation, and brightness (Blanco et al. 2005). If UV irradiation similarly affects plumage color in American redstarts, birds in the more open and harsh scrub habitats should be brighter than those in mangrove, yet we observe the opposite pattern, with birds in the shady, mangrove habitat having brighter plumage.

Another hypothesis is that because the light environment differs between scrub and mangrove forests, brighter individuals may be better suited to the dark environment of the mangrove forests (Endler 1992, Marchetti 1993). For example, the amount of white on the tail feathers of Myioborus redstarts increases the effectiveness of flushpursuit foraging (Mumme 2002) and darker conditions favor larger white tail patches (Jablonski et al. 2006). American redstarts also use a moderate amount of tailfanning to elicit a flush response from prey (Sherry and Holmes 1997). However, all age- and sex-classes of redstarts settle disproportionately in mangrove habitats upon arrival to Jamaica, but as density increases, dominant individuals then displace subordinates to scrub habitat (Marra 2000). Furthermore, removal experiments in Jamaica demonstrate that redstarts in poor-quality scrub habitat readily move in and occupy mangrove habitat (Marra et al. 1993, Studds and Marra 2005). Thus, it is unlikely that birds settle differentially in mangrove and scrub habitats based on the suitability of their feather brightness for eliciting a flush response from prey items.
A final hypothesis is that patterns of habitat occupancy in Jamaica may be related to geographic variation in plumage coloration across the breeding range, whereby birds from different breeding/molting locations settle differentially in high- and low-quality habitats. A recent study by Norris et al. (2007) suggested that red chroma in American redstart feathers varies geographically across the breeding range, with birds from more northerly locations (inferred by stable-hydrogen isotope analysis) having higher red chroma values, indicative of higher carotenoid content. Although, our stable-hydrogen isotope $\delta \mathrm{D}$ ) analyses indicate that our over-wintering population molts over a broad latitudinal range ( $\delta \mathrm{D}$ range: -59 to $-100 \%$ ), we failed to detect a relationship between $\delta \mathrm{D}$ and plumage color. However, because the Norris et al. (2007) study was based on samples collected across the wintering range, it is possible that geographic variation in feather color is detectable at broad spatial scales (i.e., across the entire range of the species), but not within a single over-wintering population. In addition to the lack of relationship between brightness or red chroma and molting latitude, we found no difference in $\delta \mathrm{D}$ between habitat types, suggesting that plumage brightness, not molt location, is a good predictor of non-breeding habitat occupancy.

Studies that have examined the role of plumage traits under varying scenarios (e.g., male-male competition versus female mate choice) and throughout the annual cycle have provided insight into the dual utility of ornamental traits (McGraw and Hill 2000, Alonso-Alvarez et al. 2004, Griggio et al. 2007), and the evolution of multiple ornaments (Andersson et al. 2002). Athough our study suggests that tail feather brightness may be a potential signal on the wintering grounds, the function of this and other plumage traits must be examined within the context of the entire annual cycle and under different conditions (e.g., female mate choice). In breeding populations of American redstarts, previous work suggests that birds with smaller bibs have higher pairing success (Lemon et al. 1992) and our preliminary analyses suggest a potential role for tail feather brightness in sexual signaling ( $\mathrm{M}$ W Reudink, unpubl. data). Longitudinal studies on the same individuals across years, combined with experimental studies, will provide important insights into the dynamics of these signaling systems. Such approaches are important for understanding if high-quality individuals are able to produce bright feathers each year regardless of environmental conditions, or if plumage coloration is highly dependent on environment and is thus a phenotypically plastic trait that reveals more about condition/environment at molt rather than intrinsic quality. Finally, studies conducted during different phases of the annual cycle can provide insight into how selection acts on both single and multiple ornaments throughout the year. We suggest that study of plumage during the non-breeding season in long-distance migratory birds is an overlooked avenue that may provide insight into the function and evolution of ornamental traits.

Acknowledgements - We thank R. Montgomerie for the use of his color analysis equipment, software, and expertise. K. Klassen and A. Vuletich provided invaluable support during isotope analysis. R. Montgomerie, R. Germain, R. Reudink, T. Murphy, and J. Nocera provided insightful comments on earlier drafts of this 
manuscript. We gratefully acknowledge the hard work and dedication of numerous field assistants, without whom this work would not be possible. Funding was provided by Queen's Univ., NSERC, Canadian Foundation for Innovation, Ontario Innovation Trust, Sigma Xi, the American Ornithologists' Union, the Canadian Society of Ornithologists, the American Museum of Natural History, and the National Science Foundation. All methods conducted in this study complied with the laws of the nations of Jamaica and Canada.

\section{References}

Albrecht, T., Schnitzer, J., Kreisinger, J., Exnerova, A., Bryja, J. and Munclinger, P. 2007. Extrapair paternity and the opportunity for sexual selection in long-distance migratory passerines. - Behav. Ecol. 18: 477-486.

Alonso-Alvarez, C., Doutrelant, C. and Sorci, G. 2004. Ultraviolet reflectance affects male-male interactions in the blue tit (Parus caeruleus ultramarinus). - Behav. Ecol. 15: 805-809.

Andersson, M. 1994. Sexual Selection. - Princeton Univ. Press.

Andersson, S. and Prager, M. 2006. Quantifying colors. - In: Hill, G. E. and McGraw, K. J. (eds). Bird coloration vol. 1: mechanisms and measurements. (eds). Harvard Univ. press, Cambridge, Massachusetts, pp. 41-89.

Andersson, S., Pryke, S. R., Örnborg, J., Lawes, M. J. and Andersson, M. 2002. Multiple receivers, multiple ornaments, and a trade-off between agonistic and epigamic signaling in a widowbird. - Am. Nat. 160: 683-691.

Bearhop, S., Furness, R. W., Hilton, G. M., Votier, S. C. and Waldron, S. 2003. A forensic approach to understanding diet and habitat use from stable isotope analysis of (avian) claw material. - Funct. Ecol. 17: 270-275.

Bearhop, S., Hilton, G. M., Votier, S. C. and Waldron, S. 2004. Stable isotope ratios indicate that body condition in migrating passerines is influenced by winter habitat. - Biol. Lett. 271: 215-218.

Blanco, G., Frias, O., Garrido-Fernandez, J. and HorneroMendez, D. 2005. Environmental-induced acquisition of nuptial plumage expression: a role of denaturation of feather carotenoproteins? - Proc. R. Soc. B 272: 1893-1900.

Dolan, A. C., Murphy, M. T., Redmond, L. J., Sexton, K. and Duffield, D. 2007. Extrapair paternity and the opportunity for sexual selection in a socially monogamous passerine. - Behav. Ecol. 18: 985-993.

Eckert, C. G. and Weatherhead, P. J. 1987. Ideal dominance distributions: a test using red-winged blackbirds (Agelaius phoeniceus). - Behav. Ecol. Sociobiol. 20: 143-152.

Endler, J. A. 1990. On the measurement and classification of colour in studies of animal patterns. - Biol. J. Linn. Soc. 41: 315-352.

Endler, J. A. 1992. Signals, signal conditions, and the direction of evolution. - Am. Nat. 139: S125-S153.

Figuerola, J., Domenech, J. and Senar, J. C. 2003. Plumage colour is related to ectosymbiont load during moult in the serin, Serinus serinus: an experimental study. - Anim. Behav. 65: 551-557.

Greenberg, R. and Marra, P. P. (eds). 2005. Birds of two worlds: The ecology and evolution of migration. - Johns Hopkins Univ. Press, Baltimore.

Griggio, M., Serra, L., Licheri, D., Monti, A. and Pilastro, A. 2007. Armaments and ornaments in the rock sparrow: a possible dual utility of a carotenoid-based feather signal. - Behav. Ecol. Sociobiol. 61: 423-433.

Hill, G. E. 1990. Female house finches prefer colourful males: sexual selection for a condition-dependent trait. - Anim. Behav. 40: 563-572.
Hill, G. E .1999. Mate choice, male quality, and carotenoid-based plumage coloration. - In: Adams, N. and Slotow, R. (eds). Proc. XXII Internat. Ornithol. Congr. Univ. of Natal, Durban, South Africa, pp. 1654-1668.

Hill, G. E. 2002. Red bird in a brown bag: the function and evolution of colorful plumage in the house finch. - Oxford Univ. Press.

Hill, G. E. 2006. Female mate choice for ornamental coloration. - In: Hill, G. E. and McGraw, K. J. (eds). Bird Coloration, vol. 2. Function and evolution. Harvard Univ. Press, pp. 137200.

Holberton, R. L., Able, K. P. and Wingfield, J. C. 1989. Status signaling in dark-eyed juncos, Junco byemalis: plumage manipulations and hormonal correlates of dominance. - Anim. Behav. 37: 681-689.

Jablonski, P. G., Lasater, K., Mumme, R. L., Borowiec, M., Cygan, J. P. and Periera, J. 2006. Habitat-specific sensoryexploitative signals in birds: propensity of dipteran prey to cause evolution of plumage variation in flush-pursuit insectivores. Evolution - 60: 2633-2642.

Johnsen, A. Andersson S., Örnborg, J. and Lifjeld, J. T. 1998. Ultraviolet plumage ornamentation affects social mate choice and sperm competition in Bluethroats (Aves: Luscinia s. svecica): A field experiment. - Proc. R. Soc. B 265: 13131318.

Lajtha, K. and Marshall, J. D. 1994. Sources of variation in isotopic composition in plants. - In: Lajtha, K. and Marshall J. D. (eds). Stable isotopes in ecological and environmental sciences. Oxford Univ. Press, pp. 1-21.

Langin, K. M., Reudink, M. W., Marra, P. P., Norris, D. R., Kyser, T. K. and Ratcliffe, L. M. 2007. Hydrogen isotopic variation in migratory bird tissues of known origin: implications for geographic assignment. - Oecologia 152: 449-452.

Lemon, R. E., Weary, D. M. and Norris, K. J. 1992. Male morphology and behavior correlate with reproductive success in the American redstart (Setophaga ruticilla). - Behav. Ecol. Sociobiol. 29: 399-403.

Linville, S. U. and Breitwisch, R. 1997. Carotenoid availability and plumage coloration in a wild population of northern cardinals. - Auk 114: 796-800.

MacDougall, A. K. and Montgomerie, R. 2003. Assortative mating by carotenoid-based plumage colour: a quality indicator in American goldfinches, Carduelis tristis. -Naturwiss. 90: 464-467.

Marchetti, K. 1993. Dark habitats and bright birds illustrate the role of environment in species divergence. - Nature 362: 149152.

Marra, P. P. 2000. The role of behavioral dominance in structuring patterns of habitat occupancy in a migrant bird during the nonbreeding season. - Behav. Ecol. 11: 299-308.

Marra, P. P., Hobson, K. A. and Holmes, R. T. 1998. Linking winter and summer events in a migratory bird by using stablecarbon isotopes - Science 282: 1884-1886.

Marra, P. P. and Holmes, R. T. 2001. Consequences of dominance-mediated habitat segregation in American redstarts during the nonbreeding season. - Auk 118: 92-104.

Marra, P. P., Sherry, T. W. and Holmes, R. T. 1993. Territorial exclusion by older males in a Neotropical migrant bird in winter: removal experiments in American redstarts (Setophaga ruticlla). - Auk 110: 565-572

Maynard Smith, J. and Harper, D. G. C. 1988. The evolution of aggression: can selection generate variability? - Phil. Trans. R. Soc. B 319: 557-570.

McGraw, K. J. 2007. Dietary mineral content influences the expression of melanin-based ornamental coloration. - Behav. Ecol. 18: 137-142.

McGraw, K. J., Dale, J., and Mackillop, E. A. 2003. Social environment during molt and the expression of melanin-based 
plumage pigmentation in male house sparrows (Passer domesticus). - Behav. Ecol. Sociobiol. 53: 350-357.

McGraw, K. J. and G. E. Hill. 2000. Carotenoid-based ornamentation and status signaling in the house finch. - Behav. Ecol. 11: 520-527.

McGraw, K. J. and Hill, G. E. 2001. Carotenoid access and intraspecific variation in plumage pigmentation in male American goldfinches (Carduelis tristis) and northern cardinals (Cardenalis cardinalis). - Funct. Ecol. 15: 732-739.

Mennill, D. J., Doucet, S. M., Montgomerie, R., and Ratcliffe, L. M. 2003. Achromatic color variation in black-capped chickadees, Poecile atricapilla: black and white signals of sex and rank. - Behav. Ecol. Sociobiol. 53: 116-122.

Møller, A. P. 1987. Variation in badge size in male house sparrows Passer domesticus: evidence for status signaling. - Anim. Behav. 35: 1637-1644.

Montgomerie, R. 2006. Analyzing colors. - In: Hill, G. E. and McGraw, K. J., (eds). Bird coloration volume 1: mechanisms and measurements. Harvard Univ. Press, pp. 90-147.

Mumme, R. L. 2002. Scare tactics in a neotropical warbler: white tail feathers enhance flush-pursuit foraging performance in the slate-throated redstart (Myioborus miniatus). - Auk 119: 10241035.

Norris, D. R., Marra, P. P., Bowen, G. J., Ratcliffe, Royle, J. A. and Kyser, T. K. 2006. Migratory connectivity of a widely distributed Neotropical-Nearctic songbird. - Ornithol. Monogr. 61: 14-28.

Norris, D. R., Marra, P. P., Kyser, T. K., Ratcliffe, L. M. and Montgomerie, R. 2007. Continent-wide variation in feather colour of a migratory songbird in relation to body condition and moulting locality. - Biol. Lett. 3: 16-19.

Norris, D. R., Marra, P. P., Kyser, T. K., Sherry, T. W. and Ratcliffe, L. M. 2004a. Tropical winter habitat limits reproductive success on the temperate breeding grounds in a migratory bird. - Proc. R. Soc. B 271: 59-64.

Norris, D. R., Marra, P. P., Montgomerie, R., Kyser, T. K. and Ratcliffe, L. M. 2004b. Reproductive effort molting latitude, and feather color in a migratory songbird. - Science 306: 2249-2250.

Peek, F. W. 1972. An experimental study of the territorial function of vocal and visual displays in the male red-winged blackbird (Agelaius pheoniceus). - Anim. Behav. 20: 112-178.

Perrault, S., Lemon, R. E. and Kuhnlein, U. 1997 Patterns and correlates of extrapair paternity in American redstarts (Setophaga ruticilla). - Behav. Ecol. 8: 612-621.

Pryke, S. R. and Andersson, S. 2003. Carotenoid-based status signaling in red-shouldered widowbirds (Euplectes axillaries): epaulet size and redness affect captive and territorial competition. - Behav. Ecol. Sociobiol. 53: 393-401.

Pryke, S. R., Andersson, S., Lawes, M.J. and Pipeer, S. E. 2002. Carotenoid status signaling in captive and wild red-collared widowbirds: independent effects of badge size and color. - Behav. Ecol. 13: 622-631.

Pryke, S. R., Lawes, M. J. and Andersson, S. 2001. Agonistic carotenoid signalling in male red-collared widowbirds: aggression related to the colour signal of both the territory owner and model intruder. - Anim. Behav. 62: 695-704.
Rohwer, S. A. 1975. The social significance of avian winter plumage variability. - Evolution 29: 593-610.

Rohwer, S. A. 1985. Dyed birds achieve higher social status than controls in Harris' sparrows. - Anim. Behav. 33: 1325-1331.

Saks, L., Ots, I. and Horak, P. 2003. Carotenoid-based plumage coloration of male greenfinches reflects health and immunocompetence. - Oecologia 134: 301-307.

SAS 2006. JMP statistical discovery 6.0.2. - Duxbury, California.

Senar, J. C. 2006. Color displays as intrasexual signals of aggression and dominance in birds. - In: Hill, G. E. and McGraw, K. J. (eds). Bird coloration volume 2: function and evolution. Harvard Univ. Press, pp. 87-136.

Senar, J. C., Domenech, J. and Camerino, M. 2005. Female siskins choose mates by the size of the yellow wing stripe. - Behav. Ecol. Sociobiol. 57: 465-469.

Sherry, T. W. and Holmes, R. T. 1997. American redstart (Setophaga ruticilla). - In: Poole, A. and Gill, F. (eds). Birds of North America, no. 277. The Acad. Natl. Sci. Philadelphia and the American Ornithologists' Union, Washington D.C.

Shawkey, M. D. and Hill, G. E. 2005. Carotenoids need structural colours to shine. - Biol. Lett. 1: 121-124.

Stein, A. C. and Uy, J. A. C. 2006. Plumage brightness predicts male mating success in the lekking golden-collared manakin, Manacus vitellinus. - Behav. Ecol. 17: 41-47.

Studds, C. E., Kyser, T. K. and Marra, P. P. 2008. Natal dispersal driven by environmental conditions interacting across the annual cycle of a migratory songbird. - Proc. Natl. Acad. Sci. 105: 2929-2933.

Studds, C. E. and Marra, P. P. 2005. Nonbreeding habitat occupancy and population processes: an upgrade experiment with a migratory bird. - Ecology 86: 2380-2385.

Studds, C. E. and Marra, P. P. 2007. Linking fluctuations in rainfall to nonbreeding season performance in a long-distance migratory bird (Setophaga ruticilla). - Climate Res. 35: 115122 .

Stutchbury, B. J. M. 1994. Competition for winter territories in a neotropical migrant: the role of age, sex and color. - Auk 111: 63-69.

Sundberg, J. and Dixon, A. 1996. Old, colourful male yellowhammers, Emberiza citrinella, benefit from extra-pair copulations. - Anim. Behav. 52: 113-122.

Thusius, K. J., Peterson, K. A., Dunn, P. O. and Whittingham, L. A. 2001. Male mask size is correlated with mating success in the common yellowthroat. - Anim. Behav. 62: 435-446.

Webster, M. S., Tarvin, K. A., Tuttle, E. M. and Pruett-Jones, S. 2007. Promiscuity drives sexual selection in a socially monogamous bird. - Evolution 61: 2205-2211.

Wolfenbarger, L. L. 1999. Is red coloration of male northern cardinals beneficial during the nonbreeding season? A test of status signaling. - Condor 101: 655-663.

Yezerinac, S. M. and Weatherhead, P. J. 1997. Extra-pair mating, male plumage coloration and sexual selection in yellow warblers (Dendroica petechia). - Proc. R. Soc. B 264: 527-532.

Zahavi, A. 1977. The cost of honesty (further remarks on the handicap principle). - J. Theor. Biol. 67: 603-605. 